\title{
Volcanic eruptions in
}

Ecuador during the Bourbon administration: between risk and disaster ${ }^{1}$

\section{Erupções vulcânicas}

no Equador durante a administração do Bourbon: entre o risco e a catástrofe

Adrián García Torres² 
Abstract: This research examines the volcanic eruptions that occurred in Ecuador in the $18^{\text {th }}$ century. It also analyses the socioeconomic impacts they caused, the emergency policies and the disaster management in the different institutions of the Bourbon administration.In this way, the eruptive cycles of the Cotopaxi volcano in 1742-1744 and 1766-1768, as well as the Tungurahua volcano in 1773-1781, are analysed. The primary documentary sources used in this paper come from different historical archives(Archivo General de Indias, Archivo General de la Nación de Colombia, Archivo Nacional del Ecuador y Archivo Histórico Nacional de España), as well as data and transcriptions of documents collected by different authorsand contemporary to the eruptions.

Keywords: Volcano; Cotopaxi; Tungurahua; Risk; 18th century.

Resumo: Esta investigação examina as erupções vulcânicas que ocorreram no Equador no século XVIII. Analisa também os impactos socioeconómicos que causaram, as políticas de emergência e a gestão de catástrofes nas diferentes instituições da administração Bourbon. Desta forma, são analisados os ciclos eruptivos do vulcão Cotopaxi em 1742-1744 e 1766-1768, bem como o vulcão Tungurahua em 1773-1781. As principais fontes documentais utilizadas nesta obra provêm de diferentes arquivos históricos (Archivo General de Indias, Archivo General de la Nación de Colombia, Archivo Nacional del Ecuador y Archivo Histórico Nacional de España), assim como dados e transcrições de documentos recolhidos por diferentes autores e contemporâneos às erupções.

Palavras-chave: Vulcão; Cotopaxi; Tungurahua; Risco; Século XVIII. 


\section{Introduction}

\subsection{Settlements in territories with natural hazards: the case of Ecuador}

When analysing the reasons why human populations settled in places where natural hazards were evident, such as volcanic risk in our case study, it's important to take different material and religious reasons into account. Indigenous Americans settled in highlands for different reasons: natural resources, especially hydrographic ones, were abundant; being able to defend themselves was assured given the orographic features of the area; and, in the religious aspect, their worship to high places fulfilled their spiritual needs. The Spanish conquerors took advantage of a good part of these urban areas or nearby places to settle in, since they soon recognised the advantages that these areas offered. On top of all that, it allowed them to control the indigenous populations against possible rebellions, as well as assign them as manpower (PETIT-BREUILH SEPÚLVEDA, 2004, p. 149-152).

Present-day Ecuador fulfils all the elements that we have discussed, since, during the colonial period, populations settled around the valleys of the interAndean region of the Andes mountain range, which had almost impenetrable walls, were rich in water supplies and had very productive lands in the proximity of the volcanoes. On this basis, the Spanish settlements expanded gradually from north to south since the $16^{\text {th }}$ century. On the other hand, founding Guayaquil, which connected the coast with Quito through the Camino Real (Royal Route), also covered the necessary connection with the sea.

It is in this geographical reality where we must place the risks that human communities had to face -and still do today-in this American territory. Ecuador is both part of the Pacific Ring of Fire and of one of its volcanic provinces, the Andean Volcanic Belt, specifically the so-called Northern Volcanic Zone (NVZ). Thus, the two dangers associated with the natural hazards in the inter-Andean region are seismic and volcanic activity. Let's not forget that seismic activity can also cause volcanic activity.

Since the arrival of European settlers in 1532 in Ecuador, eight volcanic complexes have been considered active. These would be, from north to south, the ice-capped Cayambe, Reventador, Guagua Pichincha, the Chacana caldera, Cotopaxi, Quilotoa, Tungurahua and Sangay. For the chronological period of the Bourbon administration in America, two of the volcanoes located in the eastern range of the Andes, Cotopaxi and Tungurahua, were the most remarkable. In 
addition, both have had recent activity (HALL, 1977).

\subsection{The 18th century in Ecuador: economic crisis and administrative reforms}

The Real Audiencia ${ }^{3}$ of Quito was a secondary area in Spanish America since it did not have important precious metal mines. The main industry in the interAndean region was the production of cloth by indigenous people in obrajes ${ }^{4}$ (CUSHNER, 1982). From the beginning of the $18^{\text {th }}$ century, this industry started to decline due to its loss of competitiveness. Another important reason for this downturn was linked to natural hazards, since the epidemics in the late $17^{\text {th }}$ century killed much of the indigenous population. Other epidemic outbreaks that occurred in the $18^{\text {th }}$ century already, primarily those in 1763 and 1785 , did not contribute to the demographic recovery either (ALCHON, 2002; BROMLEY, 1979; TYRER, 1988). The climate also brought on damaging atmospheric phenomena, mainly in the last decade of the $17^{\text {th }}$ century until the 20 s of the $18^{\text {th }}$ century, as well as in the last decades of the latter (DOMÍNGUEZ CASTRO et al, 2018). There were destructive earthquakes in 1698, 1755, 1757, 1786 and the most devastating of them all in 1797 (BEAUVAL et al., 2010). In this context, the eruptions of the Cotopaxi and Tungurahua volcanoes also had a big impact on the worsening of the situation. The difficulties of the $18^{\text {th }}$ century resulted in different uprisings against the Spanish administration, among which the one that happened in Quito in 1765 and the other numerous indigenous ones stand out (ANDRIEN, 1990, 2002; MCFARLANE, 1989; MORENO YÁÑEZ, 2014; MINCHOM, 2007).

Regarding the institutional and administrative situation, it's important to point out the changes introduced by the Bourbons. The Real Audiencia of Quito disappeared in 1717 and joined the newly founded Viceroyalty of New Granada until its dissolution for economic reasons in 1723. The Real Audiencia of Quito, however, was reinstated in 1720, depending, this time, on the Viceroyalty of Peru. This situation would remain in this way until 1739 , at which time the Ecuadorian territories - with their Real Audiencia- moved on to definitively form part of the restored Viceroyalty of New Granada until the end of the colonial era. The intendancy system managed to be organised in the final decades of the century, but it never really materialised beyond Quito (MAQUEDA ABREU, 2008). 


\subsection{Objectives, methodology and sources}

The volcanic activity of Cotopaxi and Tungurahua is the best example available to us to understand the socio-economic impacts of their eruptions and the role the Bourbon administration played in managing volcanic risk. This overall double objective allows for other specific objectives, since we can delve into what kind of social responses were taken during and after an eruptive event, how research on socio-economic impact was carried out, how the different administrative levels were structured, and which malfunctions appeared (ALBEROLA ROMÁ, 2019).

In order to try to carry out a detailed follow-up of the existing official documentary traces about the impact of the volcanic risk and how the Bourbon administration managed it, from the bottom of the administrative and institutional pyramid to the top, it was necessary to consult different historical archives. In the Archivo Nacional del Ecuador, the correspondence received by the president of the Real Audiencia of Quito, as well as the files he had to manage, directly or indirectly related to volcanic eruptions, was remarkable. In the Archivo General de la Nación de Colombia, you can find the files and information sent there from Ecuador, since it was the institutional and administrative authority of first instance. In the Archivo General de Indias, the final procedures of the files sent from America along with the resolutions taken by the Council of the Indies can be found. Finally, in the Archivo Histórico Nacional de España, we have reviewed the royal charters in order to find out whether or not the monarch enacted any tax exemption measures after the most important eruptive events ${ }^{5}$. On the other hand, we have expanded these data with those provided by different authors, especially with transcriptions of official documents, as well as with descriptions by people contemporary to the eruptions.

\section{The Cotopaxi Volcano}

The Cotopaxi Volcano is a stratovolcano located in the eastern mountain range of the Andes, in the current canton of Latacunga, in the province of Cotopaxi, $45 \mathrm{~km}$ southeast of Quito and $40 \mathrm{~km}$ north of Latacunga. Reaching an elevation of 5,897 metres above sea level, it is characterised by its steep profile as well as by its explosive and periodic eruptions. It is covered by a significant ice cap, with an area of $14 \mathrm{~km}^{2}$ and a volume of at least $0.7 \mathrm{~km}^{3}$, which, at 
the same time, represents its greatest associated risk due to the formation of primary lahars during its eruptions, especially on its southern slope. Five main eruptive cycles have occurred in the historical period since the arrival of the Europeans to America: 1532-1534, 1742-1744, 1766-1768, 1853-1854 and 18771880. Among the Cotopaxi eruptions, the ones in 1532, 1742, 1744, 1768 and 1877 were the most prominent ones (ANDRADE et al., 2005, p. 13-14; HALL; MOTES, 2008; ORDOÑEZ et al., 2013). As we can see, there are two eruptive cycles and three eruptive episodes relevant to our study period.

\subsection{The eruptive cycle of 1742-1744}

After more than two centuries without volcanic activity, the Cotopaxi Volcano erupted again in 1742. The most important source for the eruptive cycle of 1742-1744 is the certification from the scribe Pedro Muñoz Chamorro, written on $8^{\text {th }}$ January 1745 , at the request of the residents of Latacunga. A transcript of the original was incorporated by Sodiro $(1877)^{6}$. This is the source that we will use as the main one since it is the closest one chronologically, and it was written in the affected area. The second source is the report of the corregidor ${ }^{7}$ of Latacunga, José Cifuentes, which was sent to the viceroy of New Granada in 1745 and recounted the same events as the previous text. For this eruptive cycle, we also have the accounts of the members of the geodesic expedition available, which add more information to the official data.

As for the volcanic episodes, the eruption that occurred in the morning of $24^{\text {th }}$ June 1742 had an approximate VEI (Volcanic Explosivity Index) of 3 . The ejection of pyroclastic flows melted the ice cap, leading to a primary lahar. It descended through the Latacunga Valley, the drainage system on the southern slope of the volcano, and joined the riverbed of the Cutuchi River, the main drainage watercourse. The residents took shelter on Mount Calvario, in order to avoid the flooding. The interesting thing is that it was pointed out that this was the protection zone used since ancient times. The most significant damages happened in the neighbourhood of San Felipe in Latacunga, where a mill and a bridge were destroyed. The residents that remained there died. The bridge located in the Colaisa Valley was also affected (SODIRO, 1877, p. 36-37).

The eruptive episode on $9^{\text {th }}$ December 1742 , with an approximate VEI of 3 , which caused another primary lahar on the southern slope, had a more relevant aftermath. The amount of water that descended was greater than in the previous episode and the Latacunga Valley was badly affected. Mills, obrajes, fulling mills, 
crops and livestock did not resist this second impact. At least sixty indigenous people died. In this way, the haciendas ${ }^{8}$ between the Callo and Salache valleys were destroyed. The economic fallout did not take long to appear, since a famine emerged as a consequence of the main foods becoming overpriced. For example, barley was sold for 4 pesos a bushel and other grains were sold at a similar price. This phenomenon actually spread through the entire province as the prices in Quito also increased, and the indigenous workers of the obrajes had to search for ways to survive on their own. Bouguer, one of the members of the geodesic expedition, provides us with the most important information about the expansion of the lahar thanks to his training as a hydrologist. In regard to its impact, he stated that between 800-900 people and a very large number of livestock died, and between 500 and 600 houses were destroyed (BOUGUER, 1749, p. 68-71).

Volcanic activity continued with minor episodes in 1743 . The eruption of $28^{\text {th }}$ September 1743caused a minor lahar in the Latacunga Valley, which did not descend very quickly. In this way, 18 river swellings were recorded between $30^{\text {th }}$ September and $4^{\text {th }}$ October, all without repercussions (SODIRO, 1877, p. 38). Juan and Ulloa referenced a major eruption in 1743. In regard to the flooding, they stated that it did not go beyond the first houses of Latacunga and that the residents were able to take shelter on Mount Calvario (JUAN; ULLOA, 1748, p. 572-573). On the other hand, they described 1743 and 1744 as years of extreme scarcity and speculation in the inter-Andean region (CEVALLOS, 1870, p. 71).

The main episode of this eruptive cycle happened at 7:30 p.m. on $30^{\text {th }}$ November 1744 , with an approximate VEI of 4 . The main novelty is that the descent of large-scale primary lahars occurred from different flanks. They descended through the riverbed of the Pita River, the northern drainage system, towards the Chillos Valley and Quito; through the Tamboyacu River, the eastern drainage system; and through the Cutuchi River, the southern drainage system, heading towards the Latacunga Valley. In Latacunga, the residents returned once again to their shelter on Mount Calvario. After the fall of pumice, the much-dreaded flood made its way to Latacunga, just like in the other nearby places, such as Mulaló. The neighbourhood of Caliente was filled with mud, stones and snow blocks. The mills, fulling mills, streets and houses on the riverbanks suffered a similar fate. The small settlement of Rumipamba was also flooded. A second flood flowed through the La Ciénega hacienda, at the head of Latacunga, and flooded a significant part of the town up to the neighbourhood of San Blas. Once the episode was over and the sun came out, 
more losses were noticeable, since the roofs of some houses collapsed due to the weight of ash and dust. Meanwhile, the neighbours tried to recover as many of their belongings as they could from what was left of their houses, which led to confusion and chaos.

On $2^{\text {nd }}$ December of the same year, panic began to spread again when, at 1:00 p.m., the sky darkened for several hours, though without any consequences. This scare was followed by frequent and heavy dust clouds that did not clear very quickly due to the scarce rainfall, so the crops got destroyed and livestock died. As for the news from other places far from the Latacunga Valley, the scribe echoed that the lahars from $30^{\text {th }}$ November also occurred on the northern and eastern slopes, resulting in human losses as well as material losses, such as bridges, obrajes, mills and livestock (SODIRO, 1877, p. 38-40). Juan and Ulloa briefly highlighted the disaster caused by the floods in the southern drainage (JUAN; ULLOA, 1748, p. 572-573). La Condamine learned about this episode in France through the correspondence he received from Quito and eyewitnesses, such as the Marquis of Maenza, the owner of the La Ciénega hacienda, who visited Paris. The ash reached Riobamba, about $80 \mathrm{~km}$ away from the volcano, and covered the fields and pastures, leading to the death of thousands of heads of livestock due to starvation. It spread from east to west, following the prevailing direction of the wind, ending up in the sea. Furthermore, the town of Puerto Napo, on the eastern slope, was severely affected by the rise of the Napo River (LA CONDAMINE, 1751, p. 157-160; WOLF, 1904, p. 70-71).

\subsubsection{Disaster management: emergency policies and procedures in the Bourbon institutions}

The man in command of the procedures in Latacunga was the corregidor José Cifuentes. The only time he had to apply emergency policies was after the episode on $30^{\text {th }}$ November 1744 . He tried to control the supplies through various orders so that there was no speculation with the grains. Thus, he collected the keys that gave access to the grains and asked the owners personally to facilitate the supplies. We need to keep in mind that there was no town council in Latacunga at the time, as it was listed as a settlement, so the highest political figure fell upon this official, who was accompanied by a sheriff and a scribe.

We have not found direct traces of the procedures taken after the eruption in the Real Audiencia of Quito but rather at the headquarters of the Viceroyalty, where there is an account from Cifuentes filed in which he tells Viceroy Eslava 
y Lazaga what had happened (AGNC, Colonia, Milicias y Marina, SC. 37,123, 19). Everything seems to indicate that, once the text was received in Quito, it was sent directly to Santa Fe de Bogotá, where the procedure was finalised. To understand why it was managed in this way, we need to consider the unusual administrative and institutional situation that existed back then, which was very peculiar and difficult. These years were full of confrontations in the Real Audiencia of Quito between Creoles and Spaniards due to the appointment of presidents of Creole origin. On $1^{\text {st }}$ June 1743, the oidor ${ }^{9}$ Manuel Rubio de Arévalo became the interim President of the Real Audiencia of Quito. This measure was taken by the Council of the Indies while this official was conducting the investigation into the complaints received against President José de Araujo y Río. It was not until March 1745 that the new President of the Real Audiencia, Fernando Félix Sánchez de Orellana, took office. Even more complex was the case of the Viceroyalty of New Granada. After it was re-established in 1739, Viceroy Sebastián de Eslava y Lazaga arrived in Cartagena de Indias in April 1740 and settled there as a result of the War of Jenkins' Ear. He lived there until the end of his term in 1749, so he never got to live in Santa Fe de Bogotá and, therefore, did not fulfil his mission of presiding over his Real Audiencia (GONZÁLEZ SUÁREZ, 1894, p. 136-138, 151-154).

\subsection{The eruptive cycle of $1766-1768$}

Cotopaxi began experiencing eruptive activity again two decades later with the episodes in 1766 and, especially, the one in 1768. The most important text stored within the official text production is the account from $20^{\text {th }}$ April 1768 of the President of the Real Audiencia of Quito, José Diguja y Villagómez. There is a transcript of this document by Wolf ${ }^{10}$ (WOLF, 1904, p. 116-120) from Latacunga, although it is also stored in the Archivo General de la Nación de Colombia (AGNC, Colonia, Historia Civil, SC. 29, 4, 57) and the Archivo General de Indias (AGI, Quito, 376). On the other hand, the most relevant source for this eruptive cycle in Latacunga is the Relación de los acaecimientos que se han padecido en este Asiento ó de Latacunga y su Jurisdicción por las erupciones del Volcan de Cotopaxi y otras causas [Account of the events that have occurred in this Settlement of Latacunga and its Jurisdiction due to the eruptions of the Cotopaxi Volcano and other causes], which was included in the petition sent to the Real Audiencia of Quito on 18th April 1768 after the eruption of the Cotopaxi Volcano. Its content is available because of Wolf's (1904, p. 112-116) 
transcription. It is a document written after the eruption in 1768, which makes a historical review of the disasters that had occurred in Latacunga triggered by earthquakes and the eruptions of the volcano.

The eruption of $10^{\text {th }}$ February 1766 had an approximate VEI of 3 . Although the lahar that descended was greater than the one in 1744, the streams did not join in the southern part to end up in the town of Latacunga, as they used to. The neighbourhood of Caliente was affected once again. The lapilli and ash fall particularly affected the Tanicuchí Valley, since it made the haciendas unproductive and a large amount of livestock died. In the coastal areas, such as Guayaquil and Portoviejo, the livestock died because the pastures had been lost (WOLF, 1904, p. 79, 114-115). According to Velasco, there was less damage in Latacunga, since there were only ruins in the area and the crops were already dried out, due to the eruptions of the 1740s and the earthquake of 1757 (VELASCO, 1841, p. 82).

The eruption of $4^{\text {th }}$ April 1768, with an approximate VEI of 4, is undoubtedly the most prominent one. From 6:00 a.m. until 3:00 p.m. the jurisdiction of Latacunga became immersed in darkness. The lapilli and ash fall covered pastures and crops while also damaging trees. The livestock lost their food and the land became sterile again. Various houses and obrajes in the jurisdiction succumbed to the weight of ash, and the fall of pumice ignited straw huts in Mulaló, resulting in human losses. The Aláquez and San Felipe rivers joined together, which made communication more complicated and brought about the fear of a flood in Latacunga (WOLF, 1904, p. 115-116).

Diguja dedicated the second part of his account from $20^{\text {th }}$ April to uncovering the news that he had received about the impact of the Cotopaxi eruption, which adds to the previous data. As it might be expected, the most relevant losses were in the areas closest to the volcano. The eruptive activity had begun a few days earlier with the expulsion of volcanic gases. Following a prelude at 2:00 a.m. on $4^{\text {th }}$ April, the eruption began at 5:30 a.m., although some activity also developed in the lateral fissures. The pyroclastic fall was very significant. The hail of volcanic bombs was followed by one of ash, lapilli and pumice. The volcanic bombs fell at a distance of between a league and a half and two leagues (5-7.5 km). The pyroclastic fall of pumice reached a distance of 6 leagues (30 km).In Mulaló, at that same distance, the burning fragments ignited straw huts, shacks and barley stacks. Of the eight people killed, three were burned inside their homes. Furthermore, the fields also burned. Meanwhile, the surrounding lands were covered with ash and lapilli, so the crops and pastures 
for livestock were lost, leading to them getting ill or dying. The primary lahars formed by the pyroclastic flow expanded on several fronts. In the northern part of the volcano, the torrent demolished bridges, and, in the southern part, two streams joined together in the Cutuchi River, causing the destruction of crops, houses, sown fields and livestock. Finally, regarding the noise of the volcanic explosions, news was collected from places as far as Popayán, north of the volcano, and Guayaquil, southwest of the volcano, where the houses trembled but there was no telluric movement.

In order to exemplify the losses, Diguja mentioned a livestock hacienda north of the volcano as the main quantitative example. At the El Pedregal hacienda, former Jesuit property, which at the time was owned by the Crown and located in the Chillos Valley, 3 indigenous people burned to death; 29 oxen, 468 heads of bovine cattle, 18,285 heads of sheep, 6 donkeys, 134 mares, 22 mules, 10 horses, and 86 pigs died, and a paddock was destroyed. Prior to the expulsion of the Jesuits, González Suárez (1894, note 82) calculated 8,000 cows and 20,000 sheep on this hacienda, which shows the impact of the eruption. The total estimate for the haciendas located in the area closest to the volcano reached 50,000 deceased heads of livestock, especially wool-bearing sheep. Another situation, caused by ash in this case, occurred in the Machachi Valley, since it made it necessary for all the livestock to be moved. The great geographical expansion of the ash fall was the great novelty of this episode, since it went beyond Quito towards the north and made its way to the city of Pasto.

Finally, Diguja concluded with a general assessment of what had happened. Despite everything described, he argued that the horror brought on by the eruption was more remarkable than the losses caused, since the final calculation of the losses generated in the vicinity of the volcano was: 11 deceased people, dead livestock, houses collapsed by the weight of ash and other houses burned, 6 wooden bridges destroyed and some devastated crops. The areas furthest from the volcano, where the fields had been covered in ash, were cleared up by rainfall over the following days, which made it possible for them to be cultivated again without problems. This would not occur in the areas located in the proximity of the volcano, filled with lapilli, which would be sterile for some years (AGI, Quito, 376). 


\subsubsection{Disaster management: emergency policies and procedures in the Bourbon institutions}

If we focus on the emergency policies applied in Latacunga, we know that its corregidor, Isidro de Yanguez y Valencia tried not to let food speculation appear in his jurisdiction. The same day of the episode, he informed the Real Audiencia of Quito that the lahar and the ash fall in Latacunga put the residents on alert due to a possible sudden rise in the prices of basic foodstuff. The ruling of the corregidor ordered that none of the people in charge of the flour supply modify the prices or there would be severe penalties; these prices would be regulated. So that there would not be a shortage of water either, he ordered the indigenous and mestizo people to open the conduit that supplied the city with water from the river (ANE, Corte Suprema, Carnicería y Pulques, 6, 29).

In the case of Quito, the first signs of the eruption were felt at 5:00 a.m. Alarm soon spread among the residents, as it was feared that the eruption would be accompanied by an earthquake, like the one suffered in 1755 . For this reason, the residents of Quito gathered in outdoor places, especially in squares, like Plaza Mayor, which was the main one. It didn't take long for Diguja and the other members of the Real Audiencia to realise the chaos that could develop with this situation in a city that had just been left completely in the dark, something that continued for quite a few hours. Panic increased with the news that Diguja received about the destruction caused by the lahar in the Chillos Valley. It was possible that Quito could be the next affected city. In this valley, there is an elevated risk brought on by lahars caused by eruptions with a highmagnitude VEI, since the rivers that rise in the volcano itself and supply the city of Quito with water flow in the valley. In addition, the agricultural production that supplied the capital was located in this area (ROBERT et al., 2009).

The first measure taken by Diguja was aimed at maintaining order in the city and preventing the empty houses from being the object of possible looting. For this reason, he ordered the cavalry and infantry companies organised in squads to patrol the city, which was difficult for them due to the lack of light, making the use of lanterns necessary. The second measure was to resort to religion, since the president, the rest of the Real Audiencia and the town council met in the Plaza Mayor and discussed the beginning of the prayers with the bishop and the ecclesiastical chapter. They prayed following the petitions of the residents that gathered there. Following Diguja's mandate, all the religious events ended in the Plaza Mayor and other squares in order to protect the population from a 
possible tremor, but also, undoubtedly, to control it (AGI, Quito, 376).

Concerning the impacts of the eruption, the data from the corregimiento ${ }^{11}$ of Latacunga were forwarded to the Real Audiencia by its corregidor, Isidro de Yanguez y Valencia. He had requested several reports of what had happened to the villages of his jurisdiction. Wolf mentions ten letters, eight of which were from priests, although he does not specify where the writing took place, one from the Marquis of Maenza and another from the Chief of Mulalillo. To this, we must add the petition from Latacunga on $18^{\text {th }}$ April 1768, in which the aforementioned historical account of the disasters caused by earthquakes and eruptions of Cotopaxi was attached (WOLF, 1904, p. 80-83).

As for the procedures carried out by the Real Audiencia, President Diguja sent the account from $20^{\text {th }}$ April to the Viceroy of New Granada, Pedro Messía de la Cerda, as a result of the news that had come to him about the episode. Another document signed, in this case, by the Real Audiencia of Quito, was sent on $2^{\text {nd }}$ May. The letter attached to the new report made it clear that their intentions were for the monarch to be made aware of the disastrous episode in order to obtain his mercy. The most relevant news had to do with emphasising the argument of the loss of wool-bearing sheep for the textile industry (AGNC, Colonia, Historia Civil, SC. 29, 4, 57). It was not until several months later that the viceroy replied to the Real Audiencia of Quito and began the procedures to send the documentation to Spain. The viceroy replied to Diguja with an official letter dated $12^{\text {th }}$ July 1768 . In the brief letter, he emphasised that he was pleased that the damage had not been as disastrous as the other previous eruptions (ANE, Presidencia de Quito, 24, 67, 35).

With this information, the viceroy informed the monarch on $28^{\text {th }}$ July 1768 through the Secretary of the Indies, Julián de Arriaga. The documentation that was sent included Diguja's account from 20 ${ }^{\text {th }}$ April and the report of the Real Audiencia of Quito from $2^{\text {nd }}$ May. In the introduction letter, the viceroy simply summarised the content of both reports briefly without going into any sort of personal assessment. The royal response was communicated to the Viceroy of New Granada and to the Real Audiencia of Quito through a letter dated $4^{\text {th }}$ April 1769, in which he acknowledged what had happened and the measures that had been taken during the episode (AGI, Quito, 376). As we can see, the documentation sent was regarded by the Council of the Indies as informative only. 


\section{The Tungurahua Volcano}

The other main volcano during the Bourbon administration in Ecuador was the Tungurahua, another stratovolcano located in the eastern mountain range of the Andes on the border of the provinces of Chimborazo and Tungurahua, with a height of 5,023 metres above sea level. Its glacier is almost residual since it is currently $0.01 \mathrm{~km}^{3}$ thick. The steep slopes on its flanks are more important. Among its most important eruptive phases, we can find four within the historical period since the arrival of the Europeans to America: 1641-1646, 1773-1781, 1886-1888 and 1916-1918. In the eruptive cycle that fits chronologically within our study, the second one, the eruption of 1773 stands out the most (HALL et al., 1999; LE PENNEC et al., 2005).

\subsection{The eruptive cycle of 1773-1781}

The eruption of 1773 is fully proven with historical documentation. However, the rest of the data provided by the consulted sources regarding the following years is more uncertain and contradictory. A good example is the fact they confused the earthquake of $30^{\text {th }}$ December 1778 with an eruption of the volcano (AGI, Quito 312, 20). Again, Diguja played a key role in the procedures carried out by the Real Audiencia of Quito. The result was a brief account sent to the monarch on $17^{\text {th }}$ July 1773 , almost three months after the episode, in which, in addition to explaining what had happened, he described the volcano and cited previous episodes.

The eruption on $23^{\text {rd }}$ April 1773 had an approximate VEI of 3. The episode began between 4:00 p.m. and 5:00 p.m. without previous activity that put the residents on alert. For this reason, the residents of the slope, especially from the town of Baños, located on the northern flank and just $8 \mathrm{~km}$ away from the volcano, had to quickly take refuge in order to escape the lahar that destroyed their homes. We must also add the continuous lapilli and ash fall, which caused the first losses in the closest territory. The Cañaverales hacienda was buried in said lapilli and ash, and the livestock died. As for the Pastaza River, the rise of its watercourse caused the destruction of its bridge, resulting in the residents having to use a bridge with movable ropes to cross it. The avalanche that formed in the part where the Chambo and Patate Rivers met and the Pastaza River rose flowed into a rocky containment dyke. As a result, the overflow accumulated for more than one league $(5 \mathrm{~km})$ Twenty-four hours later, the streammanaged 
to get over the retention and broke through it. During the eruption, lateral volcanic fissures also opened up, through which lava began spilling out. The explosions of the volcano continued throughout that night and the following day, and the lava flows descended on the north and northwest flanks until reaching the river.

The activity continued for about a month with noise from explosions and with ash fall. The westward wind moved the volcanic cloud far away from the corregimiento of Riobamba. Agriculture and livestock were seriously affected, as the land was covered with ash and crops were burned. Thousands of sheep died due to the lack of food, just like the cows, oxen, etc. Thus, in five coexisting sheep farms located in the areas where there was ash fall, 4,578 heads of sheep died, despite the transfers that took place. As for agriculture, wheat, barley, corn and potato crops were lost entirely in some cases (AGI, Quito, 376).

\subsection{Disaster management: emergency policies and procedures in the Bourbon institutions}

Regarding the actions taken by Diguja in the affected area, there is a reference that takes us to one month after the disaster. Vicente de Villavicencio y Guerrero, an important hacienda owner and a native of Riobamba who had settled in Quito, forwarded the news that the administrators of his haciendas had sent him shortly after the eruption. The effects that the eruption had on his properties were that the pastures destined for the large and small-sized livestock were covered with ash. In the Riobamba and Guaranda jurisdictions, the ash had reached a height of more than a yard and a half $(129.6 \mathrm{~cm})$ in the fields. Given this situation, he asked the owners of other haciendas that had not been affected by the ash fall in both jurisdictions to take in his livestock, especially sheep, while his fields recovered. In order to fulfil this, he requested that the corregidores of Riobamba and Guaranda order indigenous people to work as shepherds and move his sheep to the closest areas, since those who cared for his haciendas would be busy trying to fix the damage inflicted to their houses, livestock and crops. This letter is not dated, and the reply given was not kept either. Unfortunately, the content summary of the volume shows that part of the documentation has been lost, since it is specified that, on $6^{\text {th }}$ May 1773, Diguja ordered the corregidor of Riobamba to help its residents (ANE, Presidencia de Quito, 32, 88, 174).

In regard to the losses caused by the disaster, president Diguja informed the 
Viceroy of New Granada, Manuel de Guirior. However, we have not discovered any additional references to him in this process, nor any letter from him in the file sent to the Council of the Indies in July, since all existing traces are linked to Diguja. The explanation for the viceroy's absence is related to the orders he received from the Crown when he was appointed. On $8^{\text {th }}$ July 1772 , he disembarked in Cartagena de Indias and, on $29^{\text {th }}$ October, he received the baton from Pedro Messía de la Cerda and took oath of office. In this city, he carried out a four-month investigation to improve the defensive system, fight contraband and pacify the Guajiro indigenous people. Given this situation, he did not set foot in Santa Fe de Bogotá until 22 ${ }^{\text {nd }}$ April 1774 (LUCENA SALMORAL, 2018).

In the report sent by Diguja to the Council of the Indies, two maps stand out, since they are the most important ones for the Bourbon administration period due to the great information that they transmit visually. Both are unsigned. If we look for clues about the authorship, there are at least two possible options. The first one is the engineer Francisco Requena, who was in Ecuador during those years, although his stay and activity were focused primarily on Guayaquil, except for a brief period in 1774 when he was sent to Cuenca. (CAPEL et al., 1983, p. 392-393; DEL RÍO SANDORIL, 2003, p. 53-57; LOARDEN RAMOS, 2012, p. 153). The other possibility is Diguja himself, as he carried out engineering work. Before his arrival in Ecuador, he participated in the construction of the Colombian Savanna roadway, and as governor of New Andalusia, Barcelona and Guyana, he organised a visit to his jurisdiction territories in 1761, which led to the creation of the Mapa que manifiesta la Gobernación de Cumaná, que consiste en su provincia, la de Barcelona y la de Guayana [Map that shows the Cumaná Governorate, consisting of the Cumaná, Barcelona and Guyana provinces], which was part of his detailed report titled Notas para la más pronta comprensión de el mapa general de la gobernación de Cumaná que dirige a S.M. en su real y supremo Consejo de Yndias, su gobernador el coronel Don José Diguja y Villagómez [Notes for the earliest understanding of the general map of the Cumaná Governorate addressed to His Majesty in his royal and supreme Council of the Indies. Signed by the Cumaná Governor, Mr Colonel José Diguja y Villagómez]. Also, we must not forget that he was the fourth commissioner in the conflict of the Treaty of Limits with Portugal, after the 1750 agreement had been broken in 1761. (GONZÁLEZ SUÁREZ, 1894, p. 283-283; LUCENA GIRALDO, 1997).

In the first map (figure 1), the data contained in the report about the territory near the volcano was developed with some brief novelty, such as the location 
of the refuge of the Andino cave for the hacienda workers and additional information about the destruction in Puela.

Figure 1 - Eruption of the Tungurahua volcano in the nearby area

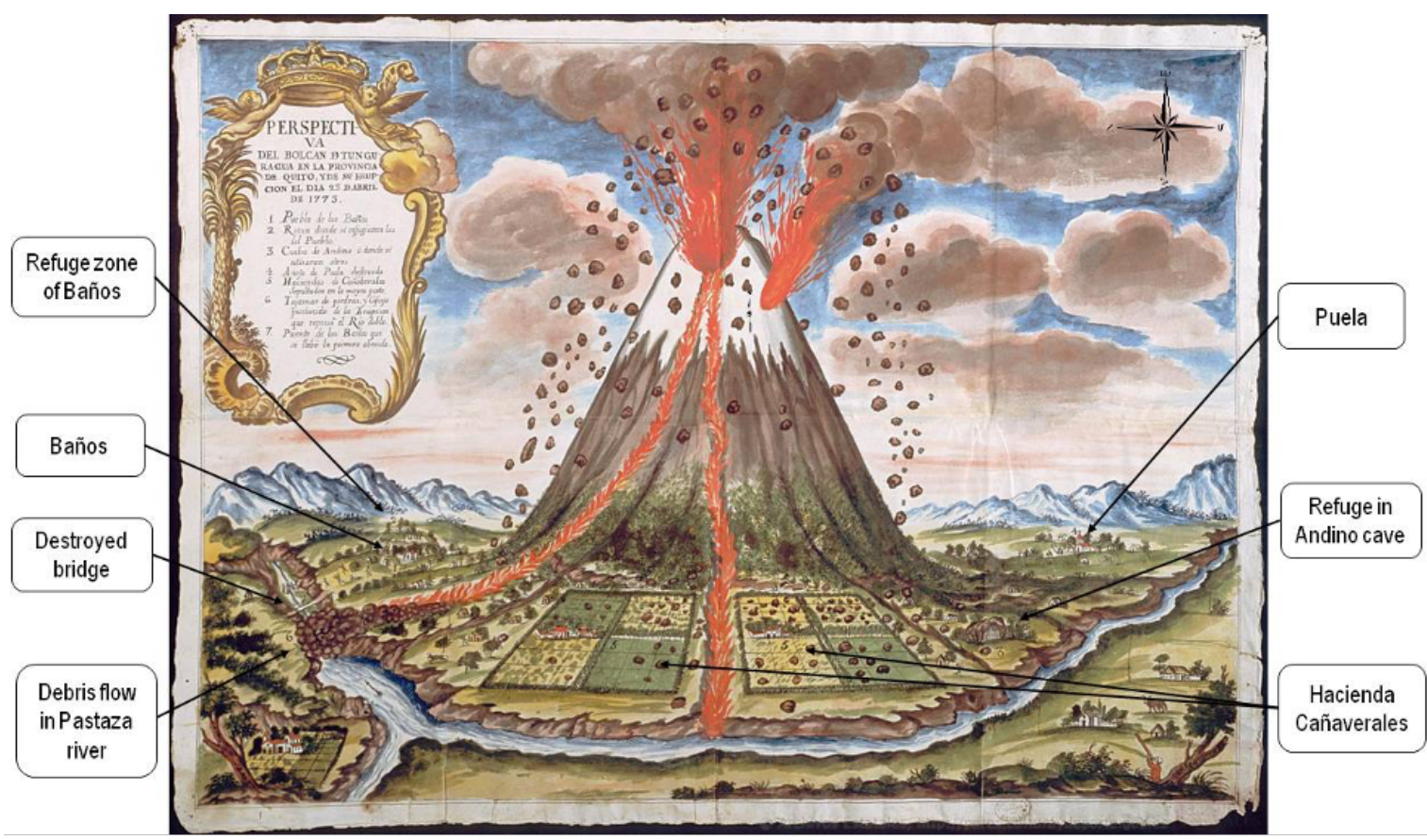

Source: AGI, MP-Panamá, 180. Elaboration: Anna Carolina Jiménez Reyes.

The second map (figure 2) is an attempt to show the extent that the lapilli and ash fall had in the corregimiento of Riobamba, in order to reinforce the content about the losses caused on haciendas. Among that information, the most important villages, haciendas, obrajes and geographical features are shown. We must emphasise that private haciendas are distinguished from those that were passed to the Crown after the expulsion of the Jesuits. If we focus on the affected haciendas, we found the ones from Cañaverales, Cahuají, Gualcanga, Sabañac, Pataló, Piscobamba and another one of which the name has not been mentioned. Some belonged to the Crown after the expulsion of the Jesuits. 
Figure 2 - Ash fall and lapilli in the corregimiento of Riobamba

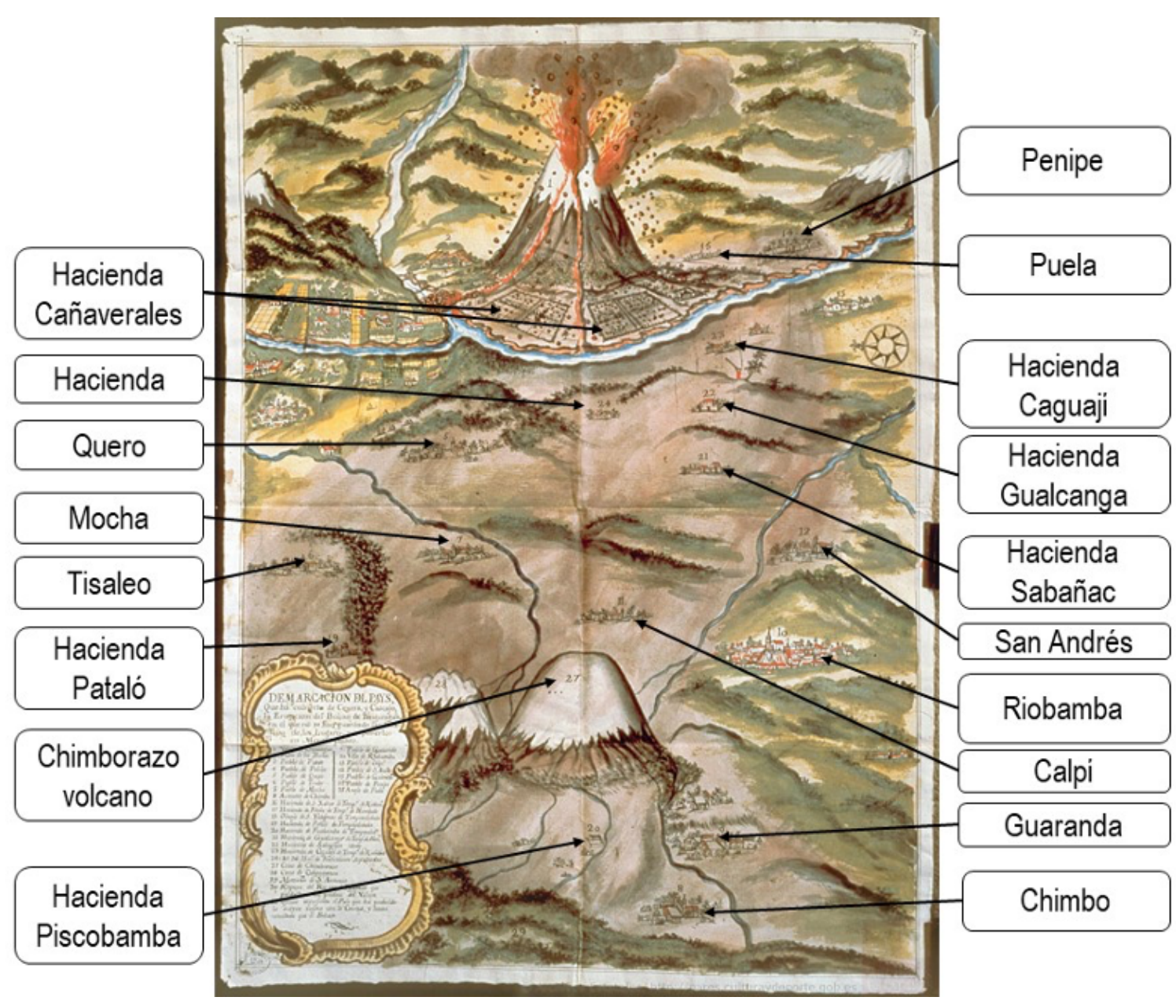

Source: AGI, Quito, MP-Panamá, 181. Elaboration: Anna Carolina Jiménez Reyes.

On $22^{\text {nd }}$ January 1774 , the Council of the Indies agreed that the documentation should be turned over to the Secretary of the Indies, Julián de Arriaga, so that he could notify the monarch of the disastrous episode. The same day, the secretary of the Council and Chamber of the Indies for Peru affairs, Miguel de Martín Cueto, sent the documents to Arriaga. He returned them to the Council of the Indies the next day for them to deal with the matter, since he had also received the same information through another private letter from Diguja dated $16^{\text {th }}$ August 1773 (AGI, Quito, 301).

The decision of the prosecutor of the Council of the Indies arrived on $6^{\text {th }}$ February 1774 . He understood the risky situation that these territories faced due to extreme natural episodes and the losses that the eruption had caused. However, he admitted that the report was too brief to assess the disaster 
exhaustively. This issue made the prosecutor doubt Diguja's intentions when he had sent all the documentation, since he had not requested any sort of measure from the Crown and it had been regarded as informative so far. For these reasons, the prosecutor ordered it be communicated to Diguja that he should report the result of the eruption and any matter that he wanted to mention, especially if he wanted to request any measure from the monarch, and also that he should provide the assistance that he deemed appropriate. The resolution of the Council of the Indies of $12^{\text {th }}$ July 1774 approved the prosecutor's statement and its content was communicated to Diguja (AGI, Quito, 376).We have not found any additional news about this process or evidence that any royal decree was enacted at a later date (AHNE, Códices, 684-725; 726-751).

\section{Final reflection}

Within the volcanic activity of the chronological period of our study, the eruptive episodes of the Cotopaxi and Tungurahua volcanoes were, without a doubt, the most relevant and the ones that offer us the most official information. The main feature that the eruptions we have reviewed have in common is that their biggest impact happened in the areas near the volcanoes, through primary lahars, and also through the fall of ash, lapilli and pumice, with a greater extent. Extensive losses in agriculture and livestock were always the most emphasised elements.

During the eruptive cycle of the Cotopaxi Volcano of 1742-1744, we can find four episodes that had socioeconomic consequences. Among them, the ones that stood out the most were the episode that occurred on $9^{\text {th }}$ December 1742 and especially the one on $30^{\text {th }}$ November 1744 , which was the most important and which entailed that it be reported to the higher administration, since the effects were cumulative. As for the eruptive cycle that occurred between 1766 and 1768, the episode in 1768 was the most relevant both for its extent and impact. Regarding the Tungurahua eruptive cycle of 1773-1781, the eruption in 1773 did not cause such important losses as the ones caused by the Cotopaxi Volcano in 1768 but they cannot be classified as minor.

The emergency policies coincide with the ones taken for other natural disasters. In the areas closest to the volcano, fighting against speculation of basic necessities was the main policy. A good example of this is found in the decrees of the corregidor of Latacunga in 1744 and 1768. In more distant and populated territories, such as the case of Quito in 1768, maintaining order 
and avoiding thefts was the main policy applied by the president of the Real Audiencia. To this, we must add the transfer of livestock to other areas, as it happened with the eruption of Cotopaxi in 1768 and Tungurahua in 1773.

When it comes to the Bourbon administrative management after an event, we find ourselves with a vertical hierarchy. The corregidor or corregidores of the affected areas, on their own initiative or by order of the Real Audiencia of Quito, collected information from the various territories in their jurisdictions in order to clarify the true socioeconomic consequences. Once the news had been collected, the president of the Real Audiencia sent information on what had happened to the highest administrative and institutional authority in America, the viceroy. His support in this type of processes was more than recommended due to the influence that the viceroy could have on the monarch when sending the documentation to the Council of the Indies. This would be the ideal procedure but, in our case study, it was not always followed. Latacunga's petition in 1745 coincided with a complex moment in the Real Audiencia of Quito, and even more so in the Viceroyalty of New Granada, so it was in Santa Fe de Bogotá where the corregidor of Latacunga's report ended. Once the normal business was resumed, in mid-March 1745, the Real Audiencia of Quito did not seem to make an effort to look into it either. With the new eruption of Cotopaxi in 1768, we did discover that the procedure was followed perfectly, since the reports that President Diguja received resulted in a summary of the general state of affairs about the eruption, which the viceroy referred to the Council of the Indies. The middle ground between both procedures was reached with the Tungurahua episode in 1773, since it was Diguja who finally sent the documentation to the Council of the Indies after informing the viceroy, who was absent at that moment.

The objective of turning to the Council of the Indies always had a triple interest: to report what had happened, to justify the actions taken by the administration during an eruption and, if it was possible, to claim tax exemptions due to agricultural and livestock losses. As for the result of the procedures in the Council of the Indies, the Cotopaxi episode in 1768 was simply regarded as informative, and Diguja's initial ruling prevailed. With the Tungurahua case of 1773, the prosecutor of the Council of the Indies had serious doubts about what the objective was, possibly due to the two highly detailed maps. Regarding the request that he made to the president of the Real Audiencia of Quito to clarify his intention regarding haciendas and livestock, there is no other procedure available. 


\section{Archival sources}

AGI, Quito, 301.

AGI, Quito 312, 20.

AGI, Quito, 376.

AGI, MP-Panamá, 180.

AGI, Quito, MP-Panamá, 181.

AGNC, Colonia, Historia Civil, SC. 29, 4, 57.

AGNC, Colonia, Milicias y Marina, SC. 37,123, 19.

AHNE, Códices, 684-725; 726-751.

ANE, Corte Suprema, Carnicería y Pulques, 6, 29.

ANE, Presidencia de Quito, 24, 67, 35.

ANE, Presidencia de Quito, 32, 88, 174.

\section{References}

ALBEROLA ROMÁ, Armando. La huella de la catástrofe en la España moderna. Reflexión en torno a los terremotos de 1748 y 1755. In: LORENZO, María Dolores; RODRÍGUEZ, Miguel; MARCILHACY, David (coord.). Historiar las catástrofes. Cidade do México: Universidad Nacional Autónoma de México, 2019, p. 67-92.

ALCHON, Suzanne Austin. Native Society and Disease in Colonial Ecuador. Cambridge: Cambridge Latin American Studies, 2002.

ANDRADE, Daniel et al. Los Peligros Volcánicos Asociados Con El Cotopaxi, Quito: Corporación Editora Nacional, 2005.

ANDRIEN, Kenneth J. Economic crisis, Taxes and the Quito Insurrection of 1765. Past \& Present, Oxford, v. 129, n. 1, p. 104-131, Nov. 1990.

ANDRIEN, Kenneth J. The Kingdom of Quito, 1690-1830: the state and regional development. Cambridge: Cambridge University Press, 2002.

BEAUVAL, Celine et al. Locations and magnitudes of historical earthquakes in 
the Sierra of Ecuador (1587-1996). Geophysical Journal International, Oxford, v. 181, n. 3, p. 1613-1633, June 2010.

BOUGUER, Pierre. La figure de la Terre... Avec une Relation abregée de ce Voyage, qui contient la description du Pays dans lequel les Opérations ont été faites. Paris: Charles-Antonie Jombert, 1749.

BROMLEY, Rosemary D. F. Urban-rural demographic contrasts in Highland Ecuador: town recession in a period of catastrophe 1778-1841.Journal of Historical Geography, London, v. 5, n. 3, p. 281-295, 1979.

CAPEL, Horacio et al. Los ingenieros militares en España, siglo XVIII: repertorio biográfico e inventario de si labor científica y espacial. Barcelona: Edicions Universitat de Barcelona, 1983.

CEVALLOS, Pedro Fermín. Resumen de la Historia del Ecuador desde su origen hasta 1845. Quito: Imprenta La Nación, 1870.

CUSHNER, Nicholas P. Farm and factory: the Jesuits and the development of agrarian capitalism in colonial Quito, 1600-1767. Albany: State University of New York, 1982.

DEL RÍO SANDORIL, José Luis. Don Francisco Requena y Herrera: una figura clave en la demarcación de los límites hispano-lusos en la cuenca del Amazonas (s. XVIII). Revista Complutense de Historia de América, Madrid, v. 29, p. 51-75, 2003.

DOMÍNGUEZ CASTRO et al. Wet and dry extremes in Quito (Ecuador) since the 17th century. International Journal of Climatology, Chichester, v. 38, n. 4, p. 20062014, 2018.

GONZÁLEZ SUÁREZ, Federico. Historia General de la República del Ecuador, Quito: Imprenta del Clero, 1894.v. 5.

HALL, Minard. El volcanismo en el Ecuador. Quito: Publicación del I.P.G.B., 1977.

HALL, Minard; MOTES, Patricia. The rhyolitic-andesitic eruptive history of Cotopaxi volcano, Ecuador. Bulletin of Volcanology, Berlin, v. 70, p. 675-702, 2008.

HALL, Minard et al. Tungurahua Volcano, Ecuador: structure, eruptive history and hazards. Journal of Volcanology and Geothermal Research, Amsterdam. v. 91, p. 1-21, 1999. 
JUAN, Jorge; ULLOA, Antonio de. Relacion historica del viage a La America Meridional hecho de orden de S. Mag para medir algunos grados de meridiano terrestre y venir por ellos en ... con otras observaciones astronomicas y... Madrid: Wentworth Press, 1748.

LA CONDAMINE, Charles Marie de. Journal du voyage fait per ordre du roi à l'Êquateur, servant d'introduction historique à la mesure de trois premiers degrés du méridien. Paris: De L’Impremiere Royale, 1751.

LE PENNEC, Jean-Luc et al. Los peligros volcánicos asociados con el Tungurahua. Quito: Corporación Editora Nacional, 2005.

LOARDEN RAMOS, Carlos. Obras civiles en América del arma de ingenieros. Revista de Historia Militar, Rio de Janeiro, n. 1, p. 137-154, 2012. Extra number.

LUCENA GIRALDO, Manuel. Laboratorio tropical: la expedición de límites al Orinoco, 1750-1767. Caracas: CSIC, 1997.

LUCENA SALMORAL, Manuel. Manuel de Guirior y Portal. 2018. Available in: http://dbe.rah.es/biografias/14901/manuel-de-guirior-y-portal. Consulted: 10 Nov. 2019.

MCFARLANE, Anthony. The "Rebellion of the Barrios": urban insurrection in Bourbon Quito. The Hispanic American Historical Review, Durham, v. 69, n. 2, p. 283-330, 1989.

MAQUEDA ABREU, Consuelo. El virreinato de Nueva Granada, 1717-1780: estudio institucional. Madrid: Dykinson, 2008.

MINCHOM, Martin, El Pueblo de Quito, 1690-1810. Demografía, dinámica sociorracial y protesta popular. Quito: FONSAL, 2007.

MORENO YÁÑEZ, Segundo E. Sublevaciones indígenas en la Audiencia de Quito. Desde comienzos del siglo XVIII hasta finales de la Colonia. Quito: Universidad Andina Simón Bolívar-Corporación Editora Nacional, 2014.

ORDOÑEZ, Jorge et al. Las potenciales zonas de inundación por lahares en el volcán Cotopaxi. Quito: Instituto Geofísico de la Escuela Politécnica Nacional, 2013.

PETIT-BREUILH SEPÚLVEDA, María Eugenia. Desastres naturales y ocupación del territorio en Hispanoamérica (siglos XVI al XX). Huelva: Universidad de Huelva, 2004. 
ROBERT, Jérémy et al. Complejidad, incertidumbre y vulnerabilidad: el riesgo asociado al volcán Cotopaxi en el Valle de los Chillos (Quito-Ecuador). Bulletin de l'Institut Français D'études Andines, [s. l.], v. 38, n. 3, p. 709-733, 2009.

SODIRO, Luis. Relación sobre la erupción del Cotopaxi acaecida el día 26 de junio de 1877. Quito: Imprenta Nacional, 1877.

TYRER, Robson Brines. Historia demográfica y económica de la Audiencia de Quito: población indígena e industria textil, 1600-1800. Quito: Banco Central del Ecuador, 1988.

VELASCO, Juan de. Historia del Reino de Quito en la Academia Meridional. Quito: Imprenta de Gobierno, 1841.v. II.

WOLF, Teodoro. Crónica de los fenómenos volcánicos y terremotos en el Ecuador: con algunas noticias sobre otros países de la América Central y Meridional desde 1533 hasta 1797. Quito: Imprenta de la Universidad Central, 1904.

\section{Notas}

${ }^{1}$ This paper is part of the APURIS program, funded by the Government of France IDEXISITE initiative 16-IDEX-001 (CAP 20-25), the Government of Spain HAR2017-82810-P and the École dels Hautes Études Hispaniques et Ibériques (Casa de Velázquez, Madrid).

${ }^{2}$ Maison des Sciences de l'Homme, Université Clermont Auvergne, CNRS, F-63000 Clermont-Ferrand, France.

${ }^{3}$ A Real Audiencia was an administrative unit in the Spanish Empire which had political, military, and religious jurisdiction over certain territories.

${ }^{4}$ An obraje was a workshop from colonial Spanish America, where mostly indigenous people produced textile articles.

${ }^{5}$ Abbreviations: AGI (Archivo General de Indias), AGNC (Archivo General de la Nación de Colombia), ANE (Archivo Nacional del Ecuador), Archivo Histórico Nacional de España (AHNE).

${ }^{6}$ Although he describes the volcanic eruption of 1887 , in the appendix he added transcribed documentation of the eruptive cycle of 1742-1744.

${ }^{7} \mathrm{~A}$ corregidor was the equivalent of a mayor during the colonial period, who was appointed by the king and had powers in administrative and judicial matters. They were the representatives of the royal jurisdiction over a town and its district.

${ }^{8} \mathrm{~A}$ hacienda was a large-scale latifundium-based agricultural estate, which normally included an architecturally valuable set of housing.

${ }^{9}$ An oidor was a member judge of the Real Audiencia.

${ }^{10}$ Geologist, botanist and explorer who, among his various studies of Ecuador in the 
$19^{\text {th }}$ century, compiled and transcribed historical sources of earthquakes and volcanic eruptions in Ecuador and other American territories.

${ }^{11} \mathrm{~A}$ corregimiento was a country subdivision for royal administrative purposes. It was usually headed by a corregidor. 